821.163.41.09:398

821.16:398

https://doi.org/10.18485/mks_srpska_slavistika.2018.2.ch17

\author{
Марија Н. КЛЕУТ \\ Драгољуб Ж. ПЕРИЋ \\ Универзитет у Новом Саду \\ Филозофски факултет \\ Одсек за српску књижевност
}

\title{
ДВОЈНИЦИ СТАРЦА МИЛИЈЕ У СВЕТЛУ ТРАДИЦИОНАЛНИХ ПРЕДСТАВА О ДВОЈНИКУ КОД СЛОВЕНА
}

\begin{abstract}
Милијина песма о Страхињи Бановићу јединствена је и у оквиру сижејног модела о неверној жени, и у оквиру варијаната. Једино у њој присутна је симетрија (двојништво) Бановић Страхиња - стари дервиш ( - певач), која се не појављује ни у једној другој песми. Заснован на прасловенским, словенским и јужнословенским представама о двојнику, а истовремено их и надилазећи, систем ликова из Милијине песме, саздан по принципу двоструких двојника, актуелизује опозиције cвој : туђи, млади : стари, богатећи их у психолошком (архетип сенке) и егзистенцијалном смислу (самоћа као цена и коб изузетности). Самим тим, циљ овога рада је да покаже како се, активирањем архетипских представа, уграђених у митски сиже и систем ликова, ослобађа снага симболичке делотворности мита, везана за пут индивидуације главног лика.

Кључне речи: двојник, систем бинарних опозиција, Старац Милија, епска песма, варијанте, епски јунак, противник, сенка.
\end{abstract}

Појединац партиципира у животу заједнице и у традиционалној култури, представља јединствену индивидуу, захваљујући опозицијама, тј. дистинктивним цртама, којима се разликује од осталих чланова колектива, са којима ступа у различите односе. Захваљујући тој јединствености, он бива препознат као наш (брат, рођак, комшија, земљак и т. сл.), односно члан одређеног социјума. Удвостручавањем „исте” јединице (нпр. рођењем близанаца) привремено се дестабилизују начела бинарног кодирања, на којима се митолошки систем заснива, да би систем поново успоставио хармонију тако што се чланови дуалног пара поларизују, те у близаначким митовима један брат постаје оличење добра, корисног, бесмртности, светлости, а други - зла, штетног, смрти, мрака (в. „Близенечные мифы”). Понекад, процес раздвајања није ишао у правцу поларизације, него близанци постају комплементарни

"kleutmaj@gmail.com 
- браћа се појављују као оличења два начела: ,један је смртан, други је бесмртан; један је благ, пасиван и интровертан, други је динамичан, агресиван и екстровертан” (Biderman 2004: 39) или близаначки пар чине брат и сестра.

Разматрајући семантику двојника у контексту његових потоњих фолклорних и литерарних сижејних трансформација, Олга Михајловна Фрејденберг генезу двојника види у удвајању једног митолошког лика - носиоца супротних црта (тј. и позитивног и негативног начела истовремено) - у два брата близанца. Том близаначком пару придружује се и лик оца, који (у односу на њих) формира нову опозицију (млади-стари), репрезентујући собом архетипске представе о старости и смрти:

Отац и двојица синова су само једна раздвојена слика, при чему је једна од њих још једном раздвојена; она је посебно типична по својој уобичајености: у старцу - оцу даје се начело смрти, у сину - обнављање и нови живот, при чему је у једном брату - фаза прелаза, у другом - завршен процес [...] Касније су то само посебне приче већ о двојици браће. Један од њих је двојник другог, али један од њих носи смртно начело и зато је или убица или просто покојник; други носи у себи небеско начело и он или кротко преживљава привремену смрт од брата, или силази у пакао да би га извео одатле. И у једном и у другом случају његова судбина је кратак сусрет са смрћу и бесмртност, судбина другог брата је - неповратна смрт. (Фрејденберг 2011: 275).

Поред тога што се представа о двојнику среће у веровањима о близанцима, „веома су распрострањена веровања да постоје мистичне везе [...] између лица рођених истог дана и истог месеца ('једноданци', 'једномесечићи') и да једно такво биће може да утиче на судбину другога, нарочито смрћу" (Filipović 1966: 150). ${ }^{1}$ Значи, осим крвног сродства, представе о двојнику могу се заснивати и на магијско-судбинској повезаности.

Поред антропоморфног двојничког пара, један од браће близанаца може имати зооморфни лик - мајмуна, говечета, коња (МНМ I 1986: 175) и сл. У индоевропској традицији Ашвини се тако повезују с птицама (Исто: 175), а Диоскури - с коњима (Исто). У словенском фолклору један од тројице браће је медвед (Иванов - Топоров 1965: 162). Распрострањена веровања у анорганског (извор, камен), астралног, биљног или анималног двојника, уочава Филиповић (1966), код Јужних Словена воде, по свој прилици, порекло из хетерогених (преанимистичких, анимистичких, дуалистичких, тотемистичких и др.) митолошких система и нису повезана искључиво са (близаначким) тотемизмом. ${ }^{2}$

Формирање бинарно кодираног система митских ликова, најпре је текло, сматра Михајловна Фрејденберг, линијом раздвајања, тј. ритуалног замењивања правог и лажног јунака, младе, младожење, светог краља и његовог карневалског двојника (роба, слуге - 2011: 278). Притом, „то су они исти двојници, исти носиоци семантике јунака који се налази у паклу. То су она иста лица на која прелази смрт - у њима је присутан и јунак и не-јунак истовремено" (Исто: 284), као бесмртна и смртна

\footnotetext{
${ }^{1}$ Представа о мистичкој повезаности људских судбина код једномесечића, као и магијском „одвезивању” живог од преминулог једномесечића, уз истовремено успостављање нове - духовне - повезаности (побратимства), дата је у Вуковом Рјечнику (в. Караџић, 1866: с.в. једномјесечићи).

${ }^{2}$ Он истиче да сачувани митски елементи у веровањима Јужних Словена, присутни у синкретизму представа, воде порекло из различитих извора и различите су старине. Они, „иако често међу собом сасвим противречни по свом основном значењу и пореклу, постоје једни поред других као равноправни делови једног заиста врло шареног мозаика, толеришући се међу собом на најлепши начин који се само може замислити" (Filipović 1966: 149).
} 
хипостаза јунака, односно његов „двојник смрти” (Исто: 285). Мушко-женски пар удвостручава се тако што ,пару богова - богу и богињи - прикључује се још један допунски пар - двојник бога и двојник богиње [...] Најпре иду комбинације линијама сродности и пријатељства: два брата, два пријатеља, мајка и маћеха, син и мајка, син и отац, пријатељ и непријатељ итд. Затим, линијама оплођења, које је касније схватано еротски: муж и жена, два мужа и две жене, муж љубавник и жена; муж, жена и љубавница" (Исто: 284-285).

Међутим, представе о двојнику у песми о Страхињи Бановићу старца Милије, већ запажане у нашој науци, ${ }^{3}$ не заснивају се нити на крвној, нити на каквој мистичкој повезаности Бановића и дервиша. На први поглед, они су, као елементи истог моделативног система, контрастно постављени и противници су, при чему је сваки од њих дефинисан као члан бинарног пара: свој-туђи, ${ }^{4}$ као и подређеним им опозицијама главни - споредни, хришћанин - муслиман, наш - противнички (ратник); млади - стари, слободни - (условно слободни), тј. роб.

При таквом устројству односа, фиксираног традиционалном културом, нема места сличности (или поистовећивању) ликова уколико они не припадају истом систему ликова (односно истом члану опозиције). Појава двојника у значењу „истог или врло сличног другом”, могућа је само у оквиру исте стране. Јунакова (наша) и противничка страна јасно су разграничене, а двојници су могући само у оквиру истог света - нашег или ґиховог. Међутим, веза се може успоставити посредством одређених обичајно-правних норми, односно духовним повезивањем, као у песми. Бан Страхињић дервиша, у ретардационо постављеној епизоди сусрета, најпре братими (Богом брате, старишу дервишу - ст. 443, 487), а затим му прашта несакупљену откупнину (цену слободе) и тако му враћа слободу и достојанство слободног човека (претходно одузето заробљавањем). ${ }^{5}$ Тим следом, стари дервиш,

\footnotetext{
${ }^{3}$ Мотив двојништва у концепцији ликова Бана Страхинића и стариша дервиша већ су истицали неки наши проучаваоци ове песме (Меденица 1965: 114; Сувајџић 2005: 35; Деретић 2006: 155-158; Љубинковић 2010: 379, 386, 395; ).

${ }^{4}$ Ова опозиција као најопштија, по мишљењу Иванова и Топорова (1965: 156-165), обухвата и неке специфичније опозиције, тј. социјално устројене бинарне парове попут: мушки - женски; старији млађи; посвећени - непосвећени; сакрални - световни; главни - споредни, слободни - неслободни (Исто: 158), али и етничке опозиције ми - иноверци (Руси - Татари; Срби - Турци), конфесионалне: хришћани - муслимани/ нехришћани (Исто: 158-159), као и митолошку опозицију људски - животињски/ демонски/ нељудски (Исто: 159-165). У усменом епском песништву, по мишљењу Иванова и Топорова, управо на опозитном пару свој - туђи (као главном типу опозиције) саздан је епски сукоб: „Применително к личностям, носящим иногда мифологизированный характер, в старое противопоставление свой-чужсй достаточно полно отражено в героическом эпосе, в частности у восточных и южных славян, хотя в зависимости от времени сложения данного варианта эпоса в старое поставление свой-чужой подставлялись новые значения членов, смотря по тому, какие враги данного коллектива были актуальны в это время, на пример: татарин, кочевник, иногда в мифологическом образе Змея-Тугарина, Идолища, Соловья-Разбойника в русских былинах; турки в южнославянских эпических сказаниях.” (Исто: 158).

${ }^{5}$ Када је реч о (пра)индоевропској основи, „међусобно слагање бројних језичких података наводи на помисао да у давнини нису куповали робу, већ људска бића. Тако је куповање првобитно значило откупљивање, јер јер откупом човек бивао ослобођен из једног привременог стања, на пример из ратног заробљеништва" (Бенвенист 2002: 81). Дакле, поновно стицање слободе могуће је тек откупљивањем. Стога, „положај роба постаје у неком смислу нормалан тек након што га купе” (Исто: 86), односно његови исплате тражену своту. Први сусрет Бана и (потоњег) дервиша, евоциран у ретроспективној епизоди, јасно успоставља систем односа господар : роб тј. заробљеник (у Бановим речима: Pопче моје, змијо од Турака - ст. 390), да би еволуирао у однос блискости, крунисан побратимством - мистички успостављеним крвним сродством, чином признања статуса равноправног, брата по избору (Виђе бане, познаде
} 
из категорије туђег, непријатеља, преводи се (побратимством као видом успостављања мистичког крвног сродства) ${ }^{6}$ у категорију свог, блиског, пријатеља. ${ }^{7}$ Захваљујући новоуспостављеној духовној вези, усаодношавање дервишеве и Бановићеве егзистенцијалне позиције могуће је, али у измењеном, модерном контексту, битно различитом од традиционалног и епског (у коме се основни сукоб успоставља антагонизмом свој- туђи).

У контексту теме о двојнику, сасвим посебан случај представља песма старца Милије Бановић Страхиња, коју је Вук Караџић публиковао најпре у другој књизи лајпцишког издања 1823, а затим у класичном бечком издању (Караџић 1988:196214). ${ }^{8}$ Издвојен из целине песме, сусрет бана и дервиша у Милијиној песми ретроспективна је епизода; статички мотив; прича о робовању стариша дервиша карактерише банову личност. Традиционалној норми усмене епике припада мотив помагача кога јунак среће на путу до противника.

Има, међутим, ова епизода значење које је искорак из традиције и индивидуални допринос великог певача. Бан Страхинић и стариша дервиш представљени су као двојници, у наративној структури песме и по особинама ликова. У песми Бановић Страхиња обојица су јунаци изван својих домова (лишени културног простора), који се срећу у пољу крај Ситнице (на отвореном). Одбачени су из своје социјалне средине, обојицу изневеравају људи којима припадају, па не добијају помоћ од оних од којих би се то очекивало: Југовићи не помажу Страхинићу, а дервиша су опљачкали Турци. И бану и дервишу двори су похарани и уништени. Обојица се прихватају оружја. Усамљени су: бан јаше сам, а дервиш пије сам. Милија коментарише положај јунака препуштеног самом себи: „Бану јутрос нема пријатеља”, а као одјек његових речи дервиш пословично каже: „Неста блага, неста пријатеља”. Дервиш „но сам лије, но сам чашу пије”, кад га сретне бан Страхинић, а бан на крају свога пута (повратка) каже: „Немам с киме ладно пити вино”. Пијење вина је у народним песмама ритуални чин учешћа у заједници, које не остварује ниједан од ова два губитника старца Милије.

дервиша, / Од ђогата коња одсједаше, / Пак загрли стариша дервиша: / „Богом брате! Старишу дервишу! /,,На поклон ти моје дуговање! - ст. 440-444).

${ }^{6}$ „Када некога братимимо, ми тражимо да се са њим вежемо везом крвнога сродства [...] Братимство је, дакле, мистички успостављено крвно сродство" (Чајкановић 1994: 52, 53 - истакао В. Ч.).

${ }^{7}$ Одређеним ритуалним и обичајно-правним поступцима (као што су побратимство или гостопримство) појединац који припада једном колективу може успоставити посебне, штавише, пријатељске односе са неким ко припада имоплеменој групи:

„појмови непријатеља, који за нас представљају три различита - семантичка и правна - ентитета, показују у старим индоевропским језицима тесну међусобну повезаност [...] Све ово може се схватити само ако се пође од представе да је сваки странац нужно непријатељ и, сходно томе, непријатељ нужно странац. Управо стога што је онај ко је рођен напољу а priori непријатељ, потребно је узајамно обавезивање да би се између њега и EGO-а успоставили гостински односи, какви не би били замисливи унутар саме заједнице. Та дијалектика 'пријатељ-непријатељ' [...] делује и у појму philos: непријатељ, чак и онај против кога се бори, може повремено постати phílos у следу споразума склопљеног уз одговарајуће обреде и освештана јемства [...] Под заштитом свечаних споразума и благодарећи узајамности могу се родити хумани односи, и тада називи за савезе или правне установе почињу да означавају осећања" (Бенвенист 2002: 238).

${ }^{8}$ Велики је број прилога који су се бавили овом знаменитом песмом. Од непосреднијег су значаја за овај рад студије Р. Меденице (1965), Н. Љубинковића (2010) и Б. Сувајџића (2005). Б. Сувајџић дао је и инструктиван преглед литературе о Милијиној песми. 
Отклон од традицијског канона велики певач остварује најпре увођењем стариша дервиша као делатног лика, а затим довођењем ликова са супротстављених (религијски и зараћених) страна и различитих (по старосној доби; један је био тамничар, а други утамничени) у исту егзистенцијалну ситуацију. ${ }^{9}$

Индивидуални допринос старца Милије добро се уочава поређењем с варијантом Анице Бегин, ${ }^{10}$ тежакиње и рибарке са Шипана, коју је записао Балдо Мелков Главић (Broz 1896: 246-259). За певачицу са Шипана утврђено је да:

„зацело је слушала и упамтила једну приморску песничку традицију о Бану [...] С друге стране, такође је јасно да је Вукова верзија, непосредно она, продрла и до Шипана и да је Аница слушала и њу - највероватније по читању из неке песмарице - јер отуда парафразира доста места и читав низ стихова" (Меденица 1965: 93).

Управо познавање предлошка (Милијине песме) и начин на који гусларка мења усвојени садржај песме омогућавају да се истакну специфичности Вуковог певача у карактеризацији ликова двојника. Хронотоп две варијанте Бановић Страхиње идентичан је до самог краја, а разлике на крају песме узроковане су изменама текста у сегменту сусрета са помагачем. Аница Бегин као помагача на Бановом путу до противника уводи младе чобанице, које право казују где се налази противник, а затим прати ток нарације у складу с овом изменом и у складу са патријархалним епским каноном: бан кажњава неверну љубу и жени се чобаницом. ${ }^{11}$ Битне разлике између Вуковог певача и Главићеве певачице, ако и нису мотивисане жељом да се у песму унесе сопствени биографски детаљ, свакако показују два супротстављена животна искуства и доживљаја света.

Повезивање два, са социјалног становишта толико удаљена, а по егзистенцијалној ситуацији и у психолошком смислу толико блиска лика, као што је примећено (Уп. Деретић 2006: 127-158), ${ }^{12}$ било је могуће само код таквог врсног певача и познаваоца људи и нарави какав је Милија: ${ }^{13}$

\footnotetext{
„Израстао из најрепрезентативније епске средине, црногорско-херцеговачке висинске области, он је доживео Бана као личност, доживео његов унутрашњи живот, сагледао његов лик, оживео Бана као човека и дао историју његове душе. Он је психологији свога јунака потчинио песничку грађу као такву и из његове психе пројицирао све сукобе и решења - нашао, дакле, уметничку солуцију њихову. Поступио је, дакле, потпуно супротно каснијим динарским певачима који имају
}

${ }^{9}$ Преглед значајне и велике базе епских народних песама (Детелић 2017) показује да се само у једној песми (Kosta Hörman. Narodne pjesme Muslimana u Bosni i Hercegovin I. Sarajevo: Svjetlost, 1976, br. 34) као „гола дервишина” јавља овај лик као делатни; у свим осталим јунаци се преоблаче у дервишке хаљине.

${ }^{10}$ Први, непотпуни попис варијаната ове песме, дао је 1935. Г. Геземан, при чему је издвојио 13 песама (Меденица 1972: 210). Поред варијаната, преглед од 35 песама у којима се појављује Бан (уз нека варирања у номинализацији) дао је Љ. Ковачевић (1889: 3-4). Тачнији, детаљнији и обухватнији попис, од преко двадесет варијаната (од чега се аутор детаљније задржава на 11 песама у којима је сижејни модел релативно стабилан, као и ликови), али и обухватну интерпретацију варијаната урадила је Клеут 2006.

${ }^{11}$ Интерпретација би свакако била потпунија да су узете у обзир песме у којима постоји лик дервиша (преузет из Милијине песме) ,код каснијих певача (нарочито Лубурићевих и Шаулића)” (Меденица 1965: 55), али је улога тамничара додељена бановом оцу. Овим се нарушава Милијина јасна слика двојника.

${ }^{12}$ Овај рад Јована Деретића први пут је објављен 1972. У овом раду сви наводи биће према Клеут 2006.

${ }^{13}$ „Милија је несумњиво највећи 'психолог’ међу Вуковим певачима. У његовом поступку приказивања ликова има највише елемената који га удаљују од старог епског схематизма и приближују једном модерном психолошком третману у каснијем роману и драми" (Деретић 2006: 141-142). 
пред очима већ готову представу, готову идеју, традицијом наметнуту, о Бану и сликају га површински у традиционалним епским контурама, не улазећи у његову психу” (Меденица 1972: 227).

Он је, сматра Љубинковић, „другачија личност од свих Вукових тадашњих и потоњих певача и казивача” (2010: 376) зато што је једини који није „као други певачи, своје песме превасходно намењивао слушаоцима”, већ је у њима казивао „себи својствену поетску и људску истину” (Исто: 378). У слици осамљеног дервиша који пије вино негде на периферији турског табора он упевава сопствени лик у матрицу епске поезије. Иконографске (старост) и ситуационе сличности (усамљеност, тражење утехе у пићу), с околностима у којима Вук приказује Милију очите су. Стога, могуће је да је певач (али и прворазредни песник) у ликовима Бана и стариша дервиша пројектовао своје искуство трагике усамљености, краха идеализма, губљења поверења у људе, вере у реч и изневеравања у невољи (Ал'да видиш јада на невољи / Бану јутрос нема пријатеља - Страхинић) и спознају несталности пријатељства (Неста блага - неста пријатеља - дервиш) - сопствени вредносни систем резонера и циничног аналитичара епске славе и њеног наличја (в. Љубинковић 2010: 376).

Двојнички пар Бан-дервиш ${ }^{14}$ Милији је послужио да у њему уопшти, отелотвори и елаборира искуство људске усамљености и одсуства подршке блиских у најтежим тренуцима. Ови ликови постављени су контрапунктно и комплементарни су:

„Бан и дервиш се допуњују на исти начин као што се допуњују први судари са светом и дугогодишње искуство [...] Стари дервиш онакав каквог га затичемо у песми представља у ствари једну од могућих консеквенци разочарања у људе, које је доживљај у првом реду главног јунака па тек онда самог дервиша. Он је онакав каквим би бан могао постати у будућности, после оног што је претрпео и проживео” (Деретић 2006: 157-158). ${ }^{15}$

Истовремено, очита је и хуманистичка порука, присутна у подтексту песме - о могућности превазилажења етничких и конфесионалних разлика.

Иако дигресивна епизода сусрета Бана и дервиша, после више година, са сижејног становишта није од већег значаја (у другим варијантама, функцију пружања информације о противниковом кретању могу преузети различити ликови: турско момче, чобанице, Турчин Хаук, турски војници - уп. Меденица 1972: 214), када је реч о психолошком портретисању главног лика, осветљеног с тачке гледишта других ликова, ретроспективно, потом ради схватања психологије Бановог поступка (некажњавање прељубнице) ${ }^{16}$ из перспективе његовог претходног живота, у про-

\footnotetext{
${ }^{14}$ О томе први пише Меденица (1965: 114).

${ }^{15}$ Сличних је ставова и Сувајџић: „Бановић Страхиња, опседнут својом интимном породичном драмом, тек је на почетку оног и онаквог пута, на чијем се крају, обремењен поразним животним искуством, находи стари Турчин” (2005: 35).

16 У науци се различито спекулисало о смислу и значењу Бановог чина, којим се, на структурној равни песме, значајно одступа од устаљеног мотивског ланца кажнена неверност (уп. Браун 2004: 210). Истицано је да „Бан прашта зато што прашта, зато што има људи који праштају и других који се свете [...] зато што је лепо праштати, што је праштати лепше но светити се; зато што је Баново праштање утолико лепше што он прашта двоструки грех своје жене; зато, најзад, што је наш песник ту лепоту осетио и истакао је као нов подвиг Банов” (Поповић 1972: 197-198). Јован Деретић овај чин тумачи, „са становишта композиције песме”, при чему уочава да „праштање неверној жени није дошло неприпремљено и неочекивано. У великој епизоди о старишу дервишу Бан је приказан као човек који је способан за племенита дела, који чини добро чак и неријатељу. Банова последња беседа у којој говори о праштању неверној жени постаје схватљива ако се доведе у везу са његовим поступцима о којима сазнајемо из приче стариша дервиша" (Деретић 2006: 130-131). Коначно, Љ. Пешикан Љуштановић разлоге бановог
} 
шлости, напосе, из певачевих личних побуда (intentio auctoris), она постаје вишеструко мотивисана, значајна и функционална. ${ }^{17}$

Милија, дакле, даје главном јунаку понешто од сопственог горког животног искуства (раскидањем веза с пријатељима и савезницима на речима, и Бана, на крају, сасвим извесно, задесиће усуд самотништва) и гради систем двоструких двојни$\kappa a:$ Милија $\approx$ стариш дервиш $\approx$ Страхиња Бановић $\approx$ Милија. „Младост Милијину оличава Бановић Страхиња [...], оно што је Вук сусрео у јесен 1822. године, јесте стариша дервиш" (Љубинковић 2010: 379). Значај који овај певач (и прворазредни песник) даје главном јунаку (у формулама на почетку и крају - на ударним позицијама у песми), те чињеница да у њега пројицира понешто и од сопственог ратничког и егзистенцијалног искуства, то што му даје слободу одлучивања (упркос канону традиције, који „исписује ток” којим се песма с темом неверне жене мора развијати, као и логичан исход, који се увек своди на кажњавање невернице) наводи на закључак да он уобличава главног јунака (и његове двојнике) не више на начин на који то чини традиција (којој је увек у фокусу колектив), него прибегава модерном поступку психолошке карактеризације у уобличавању лика изузетног јунака.

Инсистирање на јединствености и индивидуалности, уочава М. Клеут, постиже се, осим карактеризације простором, изведене њиховом физичком издвојеношћу и изолованошћу, још и карактеризацијом бројем:

„Бан се својом једнином/јединственошћу издваја из окружења које чине девет Југовића (’ђеце деветоро'); на исти начин певач представља и његовог двојника - 'Но бијаше један стари дервиш' - који се издваја као човек с ликом из безличне силне војске. Паралелизмом броја (један соко : један стари дервиш) сугерира се истоветност трагичног положаја два јунака. Најзад, поменом броја један бан ће наговестити своју судбину: 'не жали ме, брате, од једнога'. Да ли је то порука да Страхинића треба жалити зато што јесте један, јединствен, издвојен, сам?” (Клеут 2012: 144).

Самоћа је саставна фаза у процесу индивидуације, која помаже јачању особе, њеној консолидацији, док је усамљеност последица (неуспеле) социјалне интеракције, принудно стање, пораз. Поетски транспонована на најважније ликове песме: Страхињу Бановића, његовог двојника - дервиша, али и противника - Влах Алију, усамљеност постаје њихова зла коб. Симболичка карактеризација бројем један детерминише сву тројицу као самотнике. У мајчином писму, пљачкаш и отмичар љубе поменут је као ,једна сила”, „самовољан Турчин Влах Алија” - ст. 130-131 (Уп. Клеут 2012: 144).

Хуманизован када коначно оствари блискост са другом зрелом индивидуом - бановом женом, Влах Алија доживљава пораз у тренутку када љубав ${ }^{18}$ (као његов начин превазилажења усамљености) постане његова слабост. Кад угледа како хрт кидише на вољену робињу (А Турчину очи испадоше, / Колико му нешто жао бјеше, / Те он гледа, што се чини шњоме - ст. 736-738), „мучна ала”, „силан” Влах Алија,

праштања налази у психолошкој јединствености Бановог лика, коју, посредно, назначује и епизода сусрета с дервишом: „Основна и најдубља мотивација бановог поступка јесте управо његова изузетност, јединственост, физичка и духовна, која је непосредно изречена у уводној и завршној формули песме, а посредно, уз остало, засведочена бановим нетипичним односом према дервишу” (2009: 43).

${ }^{17}$ В. Деретић 2006: 131.

18 Да је мотив љубави присутан у карактеризацији јунака, ,али не у вези с ликом јунака, него с ликом његовог противника, Влах-Алије”, приметио је први Ј. Деретић (2006: 143). 
попушта стисак смрти, а љубав која га оплемењује постаје разлог његовог пораза. Страхињић, у том моменту, последњу снагу црпе из безизлаза и очаја и односи Пирову победу, спасавајући не ону коју воли, већ ону за коју му дужност налаже да је спасе (в. Деретић 2006: 143), ону која га је издала, која брани другог - свог отмичара. ${ }^{19}$

Антагонисти, јунак и противник, приказани су као усамљеници (један својевољно, други - издајом најближих) - и просторном карактеризацијом, и карактеризацијом бројем и егзистенцијално. ${ }^{20}$ Обојица су трагични у својој љубави или немогућности да је остваре (Бан бира жену из свог социјума и не успева са њом да се зближи; противнику то успева, пошто је отме супротној страни). И Бан (прослављен и дворен, али остављен у невољи) и његов непријатељ (толерисани одметник, пуштен да чини по своме) губе везу са својим примарним колективом. Влах Алија, обестан, дрзак, храбар и осион, као да представља сенку (в. Јунг 1996: 194$203)$ главног јунака, оличавајући негативну страну јуначког погледа на свет - самопотврђивање које се троши у славољубивости, „хиперболисаном индивидуализму”, сталној потреби за доказивањем, самовољи и осионости (в. Браун 2004: 11).

Откривање сличности у наизглед несличном на равни психолошке карактеризације јунака и његовог опонента показује право Милијино мајсторство у портретизацији ликова. На почетку песме, Страхинић је приказан као неко ко је свестан сопствене вредности и поносан на своју славу. Церемонијални дочек и указивање части и признања у тазбини прија му и он се томе препушта:

\author{
„Позадуго бане гостовао, \\ Позадуго бане зачамао, \\ Поноси се бане у тазбини" (ст. 61-63).
}

„Безбрига, доколица, испразни живот у Крушевцу, уживање у скоројевићским благодатима учинили су да бан [...] зачама" (Љубинковић 2010: 394), да отупи у њему свест о сопственој дужности и обавези. Све ће то, касније, изоштрити грижа савести - тј. „свест о сопственој кривици” (Исто: 381). Мрачно наличје (властитог) поноса јунак препознаје у својој сенци, противнику - сопственом у одразу у огледалу. И као израз тог препознавања јавља се еруптивни бес (уочљив у јунаковом атипичном изазивању противника на двобој), што кулминира анималним детаљем клања противника зубима, који као да израња из мрачних дубина колективног несвесног и њихових митско-ритуалних транспозиција (в. Лома 2002: 88-89) и наиз-

19 Због недостатка простора нећемо се задржавати на њеном лику, као ни мотивацији њене издаје, нити је то предмет рада. Уместо тога, довољно је указати на сцену којом певач отвара слику бојишта - на Голеч планини, надомак врата чадора, лежи силник, положивши Бановој љуби клаву у крило (Колико је њему мила била / Та робиња љуба Страхинова, / Пануо јој главом на криоце, / Она држи силна ВлахАлију - стр. 523-526). Овај призор, као и положај тела ликова, откривају међусобну блискост, однос поверења, препуштања и преданости: „Бунтовник, борац и луталица, диваљ и неукротив, од кога зазире и сам цар и цареви доглавници, нашао је мир и својеврсно опуштање у крилу банове супруге" (Љубинковић 2010: 387).

${ }^{20}$ Ту једва приметну црту у карактеризацији ова два лика издваја и Б. Сувајџић: „Влах Алија је отпадник од 'цара честитога'. Певач смишљено инсистира на његовој усамљености. Самоћа као егзистенцијална категорија повезује све учеснике у радњи песме” (2005: 33). 
глед је потпуно неспојив с углађеним и поноситим соколом с почетка песме, Страхињом Бановићем.

Овај Милијин поступак психолошког портретисања епског јунака нема паралеле ни у једној другој епској песми. Једино би се дао се поредити с поступком мајстора психолошког романа - Ф. М. Достојевског, који, у виђењу Лотмана и Мелетинског, у лику Раскољњикова „обједињава 'џентлмена' и 'разбојника', чије порекло, на крају крајева, води од 'вукодлака' и митолошких двојника-близанаца"” (Мелетински 2011: 156). Овај „спој јунака и антијунака у једном лицу, преношење борбе добра и зла-хаоса у човекову душу” (Исто: 157) представља „унутрашње двојништво” (Исто: 156). Међутим, они могу бити и раздвојени, а сенка екстериоризована - спољашњим двојником - Свидригајловим, кога с Раскољњиковим спаја „,аморалистички индивидуализам” (Исто: 160). ${ }^{21}$ Код Милије Влах Алија је Страхињићева сенка и спољашњи двојник из противничког табора по снази и јунаштву (али и по поноситости и частољубивости).

Откривајући своје „друго ја” у Влах Алији и побеђујући га, Страхиња Бановић пролази кроз преображај и довршава свој пут индивидуације:

\footnotetext{
„Бан, који се враћа из Косова, након сусрета са старишом дервишом, после мегдана са Влах Алијом, након свих доживљених сазнања и преживљених разочарења - није више исти, безбрижни, самоуверени великаш који је дошао у Крушевац [...] Дошао је тренутак да се Бан поново нађе, да након толикога лутања изнова себе нађе и себи се врати. У бану се пробудио наново нетко"
} (Љубинковић 2010: 392, 394 - истакао Н. Љ.).

Коначно, слојевитост и семантичко богатство Милијиног поетског рукописа (демонстрирано на примеру двојника) показују како је врсни певач, користећи интернационални сиже о отмици жене и систем ликова који припадају митском, ${ }^{22}$ архетипском ${ }^{23}$ и епском коду и уметнички их транспонујући у песму о изузетном јунаку и дајући им психолошку заснованост, постигао невероватну експресивност и значењски пробој активирањем управо тих древних, подтекстуалних значења. Архаичну причу о сукобу јунака с отмичарем оживотворио је уградивши у јунака део сопственог бића и судбине, док сам, попут великих трагичара, обликује познату архетипски сиже о мучној борби хероја и сила зла, јунака и његове сенке (оличене у историјском непријатељу) - у ствари борбу са самим собом (и пут досезања до највишег степена сопства), борбу која ће свој смирај досегнути с ону страну епског - у усамљеном дервишу, Милијином поетском алтер-егу.

${ }^{21}$ Као и Милија, и Достојевски у Браћи Карамазовима гради мултиплицирани систем двојничких парова: Иван Карамазов - лакеј Смердјаков; Иванова мајка - Лизавета Смрадна; Катарина Ивановна - Грушењка (в. Мелетински 2011: 190-202)

${ }_{22}^{2}$ Митски подтекст песме Бановић Страхиња, и поред неких постојећих покушаја, и даље није добио неко задовољавајуће тумачење.

${ }^{23}$ Мелетински реконструише архетипску причу о отмици жене: „Повраћај отете жене после борбе против чудовишта има многобројне паралеле [...] у најразноврснијим полумитским приповедањима и јуначком епу, која се ослањају на несумњиву реалну основу из свакидашњег живота. При томе се врло често отета жена јавља као жена јунака који креће у потрагу за њеним отмичарем” (2011: 94), с тим што „црте змаја (аждаје) или другог чудовишта дуго се задржавају у епу као атрибут непријатеља” (Исто: 95), на шта указује и несумњиво митско атрибуирање Бановог непријатеља, преведено у песми у домен метафоре - у ,мучну алу силна Влах-Алију” - ст. 640. 


\section{Извори}

MНM I: „Близенечные мифы.” Мифы народов мира.

$<$ http://www.indostan.ru/biblioteka/knigi/2730/3412_1_o.pdf .> 10. 1. 2018.

Детелић М., Томић Б. Епска народна поезија. <http://www.monumentaserbica.com/ $\mathrm{epp} / .>$ 8. 12. 2017.

Караџић В. Српски рјечник: истумачен њемачкијем и латинскијем ријечима (1818). Сабрана дела Вука Караџића. Књ. 2. Прир. Павле Ивић. Београд: Просвета, 1966.

Караџић В. Српске народне пјесме: Књига друга у којој су пјесме јуначке најстаpuje. Сабрана дела Вука Караџића. Књ. 5. Прир. Радмила Пешић. Београд: Просвета, 1988.

\section{Лuтература}

Браун М. Српскохрватска јуначка песма. Београд: Завод за уџбенике и наставна средства - Вукова задужбина, Нови Сад: Матица српска, 2004.

Деретић Ј. „'Бановић Страхиња': структура и значење.” Реликвије из старине. Прир. Марија Клеут. Нови Сад: Дневник, 2006.

Иванов В. В., Топоров В. Н. Славянские языковые моделирующие системы. Москва: Наука, 1965.

Јунг К. Г. Човек и његови симболи. Београд: Народна књига - Алфа, 1996.

Клеут М. (Прир.). Реликвије из старине: огледи о српским епским народним песмама. Нови Сад: Дневник, 2006.

Клеут М. Из Вукове сенке: огледи о народном песништву. Београд: Друштво за српски језик и књижевност Србије, 2012.

Ковачевић Љ. Страхињић Бан. Прилог проучавағу народних песама. Београд: Српско-краљевска државна штампарија, 1889.

Лома А. Пракосово: словенски и индоевропски корени српске епике. Београд: Балканолошки институт САНУ, 2002.

Љубинковић Н. Трагања и одговори. Студије из народне књижевности и фолклора I. Београд: Институт за књижевност и уметност, 2010.

Меденица Р. Бановић Страхиња у кругу варијаната и тема о невери жене у народној епици. Београд: Српска академија наука и уметности, 1965.

Меденица Р. „Бановић Страхиња у кругу варијаната.” Народна књижевност. Приредио В. Недић, Београд: Нолит, 1972: 210-227.

Мелетински Ј. О књижевним архетиповима. Сремски Карловци - Нови Сад: Издавачка књижарница Зорана Стојановића, 2011.

Пешикан Љуштановић Љ. Кад је била кнежева вечера? Нови Сад: Позоришни музеј Војводине 2009.

Поповић Б. „О последњим стиховима песме 'Бановић Страхиња'.” Народна књижевност. Приредио В. Недић, Београд: Нолит, 1972: 183-198.

Сувајџић Б. Јунаци и маске: тумачења српске усмене епике. Београд: Друштво за српски језик и књижевност Србије, 2005. 
Чајкановић В. О врховном богу у старој српској религији: Сабрана дела из српске религије и фолклора. Књ 3. Прир. Војислав Ђурић. Београд: Српска књижевна задруга - Београдски издавачко-графички завод - Просвета - Партенон М. А. M, 1994.

Biderman H. Rečnik simbola. Beograd: Plato, 2004.

Broz I., Bosanac S. Hrvatske narodne pjesme. Junačke pjesme I. Zagreb: Matica hrvatska, 1896.

Filipović M. „Čovekov dvojnik u narodnom verovanju Južnih Slovena.” Radovi 30: Odeljenje društvenih nauka, knj. 10 (1966): str. 149-184.

Мария Н. Клеут, Драголюб Ж. Перич

ДВОЙНИКИ СТАРИКА МИЛИИ В СВЕТЕ ТРАДИЦИОННЫХ ПРЕДСТАВЛЕНИЯХ О ДВОЙНИКЕ У СЛОВЯН

Резюме

Песня старика Милии о Страхине Бановиче единая как в рамках сюжетной модели о прелюбодейке, так и между её вариантами. Только в этой песне есть симметрия (двойничество) Банович Страхиня старый дервиш (- певец), которая не оказывается ещё ни в одной песне. Основанный на праславянскими, славянскими и южнославянскими представлениями о двойнике, одновременно и превосходя их, система персонажей в песне старика Милии, создаеммая по принципе дублированных двойниках, актуелизует противопоставлениях свой : чужой, младший : стариий, укрепляя их в психологическом (архетип тени) и в екзистенциальном смысле (одиночество као стоимость и рок единсвенности). Поэтому, цель этой статье показать как можно, активированием мифических представлениях, встроенных в архетипически сюжет и систему персонажей героической песни, освободить силу символической эффективности мифа, связанной с процессом индивидуализации героя - Страхини Бановича.

Опорные слова: двойник, система противопоставлений, старик Милия, геройческий эпос, варианты, эпический герой, враг, тень. 